\title{
The Effects of Yield and Morphological Treats on Forage Sorghum (Speed Feed Variety) at Single Row and Double Row Patterns in Gorleston Province Fields
}

\author{
Alireza Saberi* \\ Agronomy and Garden Research Department, Iran
}

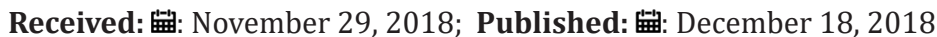

*Corresponding author: Alireza Saberi, Assistant Professor, Agronomy and Garden Research Department, Iran

\begin{abstract}
In order to comparing single row and double row planting arrangement of forage sorghum (Speed feed hybrid) and effects on yield and morphological treats, two separate experiments have been done on two regions (Gorgon and Aliabad). The experiment conducted on two levels of single row and double row with $15 \mathrm{~cm}$ space by plant density of 250000 plants per hectare. The lengths of planting lines were 66.6 meters and inter row spacing for all treatments were $65 \mathrm{~cm}$. The number of planting reasebed for each treatment were 46 reasebed and harvested area were $2000 \mathrm{~m}^{2}$ for each treatment and totally $4000 \mathrm{~m}^{2}$. For measurements of agronomical and morphological treats i.e., plant height, number of tillers, stem diameters and number of node quadrate applied, and 10 bushes randomly sampled. Total planted area also harvested and recorded. For data analysis $\mathrm{t}$ test applied. Results showed that Fresh yield of double row with $15 \mathrm{~cm}$ spacing had \% 21 priorities on first harvest and \%21.7 on the second harvest. It might be concluded that by using double row planting pattern the inter plant competition could be decreased and higher yield might be produced.
\end{abstract}

Keywords: Planting Pattern; Plant Density; Morphological Treats; Forage Yield

\section{Introduction}

With the increase in world population, demand for food consequently will grow. It is expected that human population will increase to over 8 billion by the year 2020 and this will worsen the current scenario of food security. Improved crop productivity over the past 50 years has resulted in increasing world food supplies up to $20 \%$ per person and reducing proportion of foodinsecure peoples living in developing countries from $57 \%$ to $27 \%$ of total population [1]. It is predicted that at least 10 million people will be hungry and malnourished in the world by the end of this century [1]. Thus, to reduce the food insecurity, crop production will have to be doubled, and produced in more environmentally sustainable ways [2]. This can be achieved by expanding the area of crop production, increasing per hectare yield and improving crop quality. Furthermore, during the second half of the past century, rise in per hectare crop productivity was due to improved or high yield potential [3]. The relationship between growth of forage sorghum under different planting pattern and plant density is not well understood. Many changes take place in plants to enable them to compete and maintain photosynthetic activity.
A consideration of the adaptation mechanisms by which density affects photosynthesis would aid the improvement of growth conditions and crop yield and would provide useful tools for future genetic engineering. Works in the late 1980s demonstrated that yields can be raised two to three-fold by using available improved varieties and appropriate agronomic techniques. But these findings need to be refined, improved and tested for local climatic, soil and crop conditions [4]. These include in the aspects of to what extent of planting pattern and plant density affect the yield and morpho-physiological parameters of forage sorghum. In addition, no comprehensive database is available on sorghum under combination of pattern and density in northern Iran. Thus, studies are still needed to improve our understanding of the effects of pattern and density for sorghum. Hence, the present study was to design with the following objectives:

\section{Objectives}

a) To determine the performance of forage sorghum

b) at different levels of plant density. 
c) To study the effect of planting arrangement on yield and morphological parameters of forage sorghum.

d) To identify how interaction of planting pattern and plant density affect yield and yield components of forage sorghum.

\section{Materials and Methods}

In order to the development and management for sorghum in summer season, the current study was conducted to find the effects of different planting pattern and plant density on yield and yield components of forage sorghum. A field experiment was conducted in 2015 at Gorgon (36ㅇN 54.00' 54으 $25.00^{\prime}, 51 \mathrm{~m}$ altitude) and Aliabad, Northern Iran. The experiment was laid out in a farmer field. The experiment conducted on two levels of single row and double row with $15 \mathrm{~cm}$ space by plant density of 250000 plants per hectare. The lengths of planting lines were 66.6 meters and inter row spacing for all treatments were $65 \mathrm{~cm}$. The number of planting reasebed for each treatment were 46 reasebed and harvested area were $2000 \mathrm{~m}^{2}$ for each treatment and totally $4000 \mathrm{~m}^{2}$. For measurements of agronomical and morphological treats i.e., plant height, number of tillers, stem diameters and number of node quadrate applied, and 10 bushes randomly sampled. Total planted area also harvested and recorded. For data analysis t test applied.

Fix distance of maize was $65 \mathrm{~cm}$ and the space among bushes on the furrow double row arrangement was $15 \mathrm{~cm}$, and for forage harvested at douching - milking stage. All observations on dates of recording were in accordance with the related statistical design.
The selected field was under wheat cultivated, after harvesting wheat on 15 June of 2015. The considered land ploughed in deep of $20-25 \mathrm{~cm}$, then with cross of desk made ready for planting. At the end the analysis of variance (ANOVA) of data was performed using the software of SAS (2004) by the proc [5]. GLM procedure and significant of means between the treatments were obtained using Duncan Multiple Range Test at $\mathrm{P}<0.05$.

\section{Results}

The results of comparing agronomic parameters of forage sorghum at four plant densities (Tables 1 \& 2) showed, that most of the forage sorghum studied characters included; total fresh weight, total dry yield, stem dry weight, leaf dry weight, stem diameter and plant height were statistically significant at 5\% probability level. In addition, above yield and yield components parameters with an increase in plant density increased. While morphological parameters got from medium plant density, in contrast plant height increased at low and high plant density. As shown at Tables $1 \& 2$, the main effect investigation of planting arrangement could not change significantly number of above treats, just increased forage dry weight, it means the benefit of planting pattern would be appear if arrange with suitable plant density. Interaction of planting pattern and plant density become significant at most forage sorghum studied characters. Combination treatment of planting patterns and location; showed: double row pattern in Gorgon produced the most total fresh weight (42.50 t/ ha) and total dry weight (5.70 t/ ha).

Table 1: Mean comparison of yield and some agronomic characteristics of forage sorghum on deferent plant density (2 years results).

\begin{tabular}{|c|c|c|c|c|c|}
\hline \multicolumn{6}{|c|}{ Mean Comparison of Yield and Some Agronomic Characteristics of Forage Sorghum on Deferent Plant Density (2 Years Results) } \\
\hline Experiment Location & $\begin{array}{c}\text { Treats/ } \\
\text { Treatment }\end{array}$ & $\begin{array}{l}\text { Total Fresh Weight } \\
(\mathrm{Kg} / \mathrm{H})\end{array}$ & $\begin{array}{l}\text { Differences with } \\
\text { Cheeck }(\mathrm{Kg} / \mathrm{H})\end{array}$ & $\begin{array}{c}\text { Total Dry Weight } \\
(\mathrm{Kg} / \mathrm{H})\end{array}$ & $\begin{array}{l}\text { Differences with } \\
\text { Cheeck }(\mathrm{Kg} / \mathrm{H})\end{array}$ \\
\hline \multirow{4}{*}{ Gorgon } & Single row & 33.92 & - & 5.43 & - \\
\hline & Double row & 42.50 & 25.2 & 5.70 & 2.10 \\
\hline & T value (Calculated) & 2.95 & $\begin{array}{l}= \\
=\end{array}$ & 0.88 & $=$ \\
\hline & $\mathrm{T}$ value (table) & 2.65 & $=$ & 2.62 & $=$ \\
\hline \multirow{3}{*}{ Aliabad } & Single row & 34.44 & $=$ & 5.07 & $=$ \\
\hline & Double row & 40.70 & 18.1 & 5.17 & 3.63 \\
\hline & $\mathrm{T}$ value (Calculated) & 3.6 & $=$ & 0.36 & $=$ \\
\hline T value (table) & $\mathrm{T}$ value (table) & 2.62 & $=$ & 2.62 & $=$ \\
\hline
\end{tabular}

Table 2: Mean comparison of yield and some agronomic characteristics of sorghum on deferent planting pattern (2 years results).

\begin{tabular}{|c|c|c|c|c|c|c|}
\hline \multicolumn{7}{|c|}{ Mean Comparison of Yield and Some Agronomic Characteristics of Sorghum on Deferent Planting Pattern (2 Years Results) } \\
\hline $\begin{array}{l}\text { Experiment } \\
\text { Location }\end{array}$ & Treats/ Treatment & $\begin{array}{l}\text { Number of } \\
\text { Leaf's }\end{array}$ & $\begin{array}{l}\text { Number of } \\
\text { Nodes }\end{array}$ & $\begin{array}{l}\text { Number of } \\
\text { Tillers }\end{array}$ & $\begin{array}{l}\text { Plant Height } \\
\text { (Cm) }\end{array}$ & $\begin{array}{l}\text { DiameterStem } \\
\text { (mm) }\end{array}$ \\
\hline \multirow{4}{*}{ Gorgon } & Single row & 7.2 & 3.9 & 1.8 & 12.7 & 160.1 \\
\hline & Double row & 6.9 & 4.0 & 3.3 & 11.9 & 159.7 \\
\hline & T value (Calculated) & 0.58 & 0.30 & 4.36 & 0.85 & 0.62 \\
\hline & $\mathrm{T}$ value (table) & 2.62 & 2.62 & 2.62 & 2.62 & 2.62 \\
\hline
\end{tabular}




\begin{tabular}{|c|c|c|c|c|c|c|}
\hline \multirow{3}{*}{ Aliabad } & Single row & 5.16 & 5.16 & 1.98 & 13.05 & 158.3 \\
\cline { 2 - 7 } & Double row & 5.1 & 5.1 & 3.2 & 1.8 & 1.59 \\
\cline { 2 - 7 } & T value (Calculated) & 0.10 & 0.10 & 4.08 & 0.62 \\
\hline $\begin{array}{c}\text { T value } \\
\text { (table) }\end{array}$ & T value (table) & 2.62 & 2.62 & 0.62 & 2.62 \\
\hline
\end{tabular}

Note: Plant density at single row and double row were same $=250000$ plant $/$ ha

The highest plant height obtained from single row in Gorgon $(160.1 \mathrm{~cm})$ and the most stem diameter also obtained from single row in Aliabad (13.05 mm), while production of dry forage at double row pattern (at the same plant densities) showed better performance. Other morphological parameters and yield components such as, number of nodes per plant (3.3) and number of tillers per plant (5.1) were the best at double row planting pattern (Table 1). Results on the second harvest showed that Fresh yield of double row with $15 \mathrm{~cm}$ spacing had $25.2 \%$ and $18.1 \%$ priority in Gorgon and Aliabad respectively. It might be concluded that by using double row planting pattern the inter plant competition could be decreased and higher yield might be produced.

\section{Discussion}

The results showed with changing planting arrangement from single row to double row plant density would increase by $21.7 \%$ without negative effect on yield. It means at minimum and medium plant density especially on one double - row pattern, the sorghum bushes grow better and produce a good yield component [6-8]. Increasing the yield at high plant density due to double row pattern, may is because of closing to square planting arrangement. The yield at low plant density due to lacking number of plants per surface and at high plant density because of competition for absorption growth elements and interference of male and females' flowers become limited [9-11] (Tables 1 \& 2) and (Figure 1).

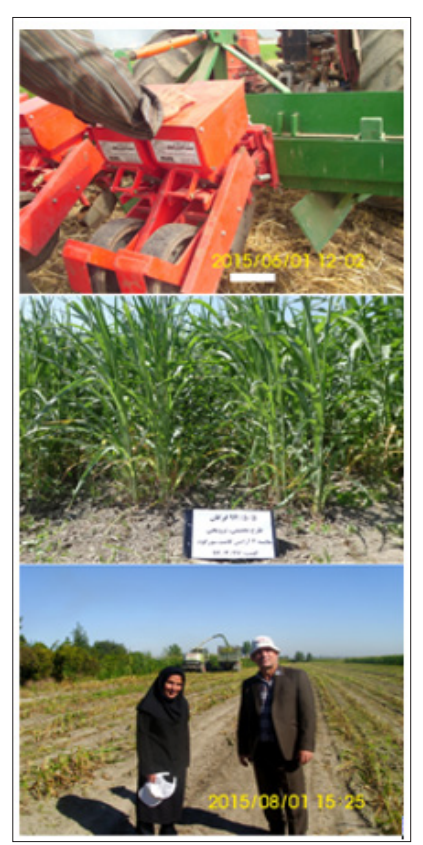

Figure 1: General pictures from experiments, showing canopy of double row planting pattern.

\section{Conclusion}

With considering double row planting arrangement, plant density would increase by $15 \%$ without negative effect on yield component and the yield could increase by $21.7 \%$. The highest forage yield was produced by 250000 plant density and 15-centimetre double row at 5\% significant (41.6t/ha). It might be concluded that by using double row planting pattern the inter plant competition could be decreased and higher yield might be attained.

\section{References}

1. FAO (2003) Fertilizer use by crop in Uzbekistan. FAO, Rome.

2. Borlaug NE, Dowswell CR (2005) Feeding a world of ten billion people: a $21^{\text {st }}$ century challenge. In: Tuberose T Phillips, RL Gale M (Eds.) Proceeding of "In the Wake of Double Helix: From the Green Revolution to the Gene Revaluation", 21-31 May 2003, at Bologna, Italy, Avenue Media, Bologna, Italy, pp. 3-24.

3. Arous JL, Slafer GA, Reynolds MP, Royo C (2004) Physiology of yield and adaptation in wheat and barley breeding. In: Blum A, Nguyen H (Eds.), physiology and biotechnology integration for plant breeding, Marcel Dekker, New York, USA, pp. 1-49.

4. Qureshi AS, Qadir M, Heydari N, Turral H, Javadi A (2007) A review of management strategies for salt-prone land and water resources in Iran. International water management Institute. 30P (IWMI working paper 125) Colombo, Sri Lanka. A Repository of Agricultural Research Outputs.

5. SAS Institute (2004) SAS/STAT user's guide. release. Release 9.0. ( $4^{\text {th }}$ edn.). Statistical Analysis Institute, Cary, NC.

6. Saberi AR, Mazaheri D, Heidari Sharif Abad H (2006) Effect of density and planting pattern on yield and some agronomic characteristics of maize KSC647. Agricultural and Natural Resources Science 1: 67-76 (In Persian).

7. Proter PM, Hicks, WE Lueschen, JH Ford, DD Warnes, et al. (1997) Corn response to row width and plant population in the northern corn-belt. J production Agric 10(2): 293-300.

8. Sprague CF, Dudly JW (1988) Corn and Corn Improvement. In Sprague CF, Dudly JW (Edn.) (3 ${ }^{\text {rd }}$ Edn), Madison, Wisconsin USA.

9. Brown RH, ER Beaty, WJ Ethedge, Hages DD (1970) Influence of row width and plant population on yield of two varieties of corn (Zea mays L). Agron J 62(6): 767-770.

10. Duncan WG (1984) A Theory to explain the relationship between corn population and grain yield. Crop Sci 24(6): 1141-1145.

11. Lutz JA, HM Comper, Jones CD (1971) Row spacing and plant Population effects on corn yield. Agron J 63: 12-14. 


\section{ISSN: 2574-1241}

DOI: 10.26717/BJSTR.2018.12.002241

Alireza Saberi. Biomed J Sci \& Tech Res

CC (i) This work is licensed under Creative

Submission Link: https://biomedres.us/submit-manuscript.php

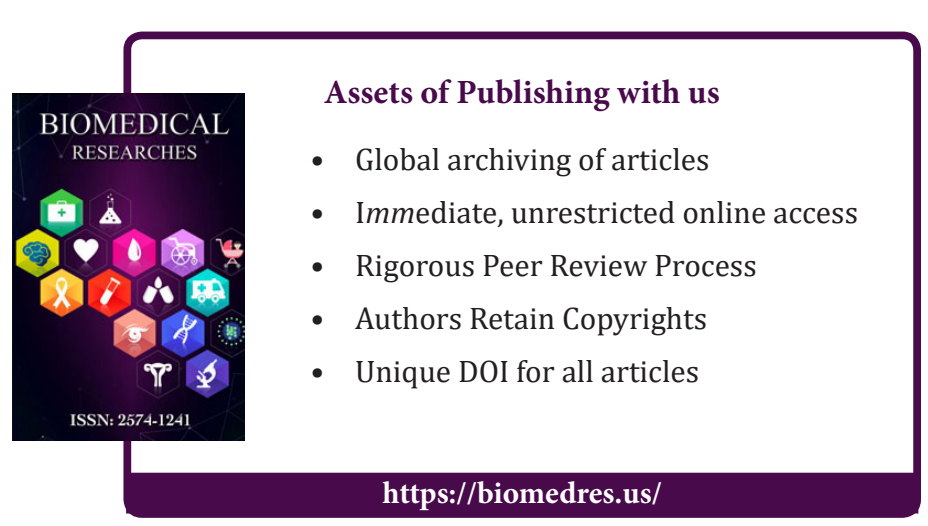

